\title{
Bénédicte Ledent and Daria Tunca, eds., Caryl Phillips, Writing in the Key of Life
}

\section{Kerry-Jane Wallart}

\section{OpenEdition}

1 Journals

Electronic version

URL: https://journals.openedition.org/ces/5884

DOI: $10.4000 /$ ces.5884

ISSN: 2534-6695

\section{Publisher}

SEPC (Société d'études des pays du Commonwealth)

\section{Printed version}

Date of publication: 1 April 2013

Number of pages: 111-112

ISSN: 2270-0633

\section{Electronic reference}

Kerry-Jane Wallart, "Bénédicte Ledent and Daria Tunca, eds., Caryl Phillips, Writing in the Key of Life", Commonwealth Essays and Studies [Online], 35.2 | 2013, Online since 17 April 2021, connection on 23 July 2021. URL: http://journals.openedition.org/ces/5884 ; DOI: https://doi.org/10.4000/ces.5884

This text was automatically generated on 23 July 2021.

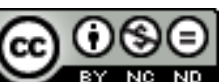

Commonwealth Essays and Studies is licensed under a Licence Creative Commons Attribution - Pas d'Utilisation Commerciale - Pas de Modification 4.0 International. 


\title{
Bénédicte Ledent and Daria Tunca, eds., Caryl Phillips, Writing in the Key of Life
}

\author{
Kerry-Jane Wallart
}

\section{REFERENCES}

Bénédicte Ledent and Daria Tunca, eds. Caryl Phillips, Writing in the Key of Life. Cross/

Cultures 146, New York and Amsterdam: Rodopi, 2012. xxi, 441 p. ISBN (hb):

9789042034556. $92 €$

1 This remarkably useful volume opens on a few texts written for the purpose of a Liège Conference held in 2006 to celebrate 25 years of writing; and if it might seem reckless to dedicate a monograph to the work of an author who not only still writes but is additionally only in his prime (he was born in 1958), such a stock-taking gesture appears as fully welcome in view of the many turns already taken by Phillips over the span of a quarter of a century. Precisely, one of the qualities of the collection is to address the generic wealth of the work, ranging from essays and plays to travelogues and half-autobiographies.

2 At the outset, there figures prominently the very autobiographical text authored by Phillips himself, "Colour me English." Drawing upon an excruciating memory of teenage racial cruelty, the Caribbean-born writer moves on to discuss the difference between his inability to fit in, and that of the other "others" in Great Britain, especially Pakistanis. He addresses the terrorist attacks of July 2005 and traces them back to "the human desire to belong" (19) that has occupied much and so many of his books. The text wonderfully gathers - and recasts - all that characterises Phillips' works: an intellectual commitment to his time, a deep-rooted autobiographical concern, a will to intertwine literary prose with an often essayistic attitude, an attempt at formulating adequate questions rather than at providing answers. In itself "Colour me English" 
justifies the enterprise of the entire volume, one which yearns to counterpoint novelistic analysis with the experience of a man and the trajectory of a thinker.

The collection edited by Ledent and Tunca otherwise comprises some 22 articles that further probe into the already prolific work of Caryl Phillips. They fall into five main items. The first one, "Autobiography, Fact and Fiction," highlights the crucial interest of the essays and more originally even, of the interviews of Caryl Phillips (Renée Schatteman, "Reflections upon an Intellectual Life"). Louise Yelin and Bénédicte Ledent then both concern themselves with the focus on the individual, the former through the lens of a diffraction or "dispersion" of the self, and the latter around the question of free will, in what she aptly calls a "paradoxical combination of defeat and dignity" (77). The following section, entitled "Caryl Phillips and the Other Writers," focuses on the influential roles of Naipaul (John McLeod), Walcott (Malik Ferdinand) and Joseph Conrad's Heart of Darkness, a novella that Phillips had prefaced for the Modern Library edition and upon which his own Heartland obviously draws (Imen Najar).

A third section, "Diasporas," is essential in its attempt at grasping the spatial poetics at work in Phillips' novels, but also its articulation with the representation of time. Stef Craps quite convincingly redirects the tools of trauma studies towards the idea, developed by Cathy Caruth, of a community being reformed because it is "implicated in each other's traumas"; the perspective allows a re-reading of Higher Ground and The Nature of Blood in the light of "linking legacies of loss." Fatim Boutros scrutinises the transhistorical dimension which has become one of the most salient - and puzzling features of Phillips' novels, with a special focus on Crossing the River and its distinct "retroactive" interpretation, while Abigail Ward grapples with the generically hybrid The Atlantic Sound and its foregrounding of a "crossing," read in the light of Said's theory. As for Wendy Knepper, she develops the imagery of water in some novels as pertaining to a "poetics of disorientation." Chika Unigwe looks at the often disregarded play writing of Phillips, with Strange Fruit, his first play and a text that is not much read or performed but certainly deserves attention (it is not always known that Caryl Phillips started his literary career as a playwright and director). "Britain and its "Others" constitutes a particularly consistent section, since the five articles it encompasses all offer an in-depth scrutiny of A Distant Shore, a pivotal novel that stands out if only because it was the first one to be set in present time. Alessandra di Maio concentrates on the myth of Englishness that it deploys and Sandra Courtman links it with the above mentioned Heart of Darkness, comparing the identity politics of both texts. The reader is also given insightful interrogations around its problematising the notions of inclusion (Thomas Bonnici), nationhood (Petra Tournay-Theodotou) as well as the deception of the opposition between civilisation and barbarism upon which the British colonial enterprise relied (Cindy Gabrielle).

5 The last section in the volume, the very climactic "Race and Masks," widens the scope by a notch to address gender issues (Lucie Gillet), a new historicist reading of Dancing in the Dark (Tsunehiko Kato), and a Freudian angle on the same 2005 novel (Itala Vivan). Dave Gunning associates Dancing in the Dark with Percival Everett's Erasure. The last paper is a long and astute reading (by Gordon Collier) of the tension between revelation and concealment; it is focused on In the Falling Snow but constantly includes other novels in relevant and impressively knowledgeable fashion. Collier all but reconciles structuralism and poststructuralism in his mastery of both close textual analysis and the foregrounding of context and perspective. 
6 Overall this monograph on Caryl Phillips provides a variety of angles without any of the repetitions that are sometimes to be found in collective volumes. An actual cohesion is secured by all the contributors' focus on the specifically personal ring in all of Phillips' books; it is thus striking to see how almost all papers question, in one form or another, the genre of the autobiography, and interrogate the essays (especially those collected in the excellent A New World Order), which are quoted and commented almost systematically. The editing of this "Cross/Cultures" issue is flawless and offers the most comprehensive overview of Caryl Phillips' oeuvre to this day, a welcome update to the already precious Caryl Phillips authored by Ledent in the "Contemporary World Writers" series (Manchester UP, 2002). The volume will surely prove crucial for scholars working on the Caribbean but also on issues of contemporary Britishness/Englishness and the like.

\section{AUTHORS}

\section{KERRY-JANE WALLART}

Kerry-Jane WALLART is Senior Lecturer at Paris-Sorbonne, where she teaches postcolonial literature. She has written a number of articles and book chapters on Caribbean authors (Derek Walcott, V. S. Naipaul, Pauline Melville, David Dabydeen, Wilson Harris, Fred d'Aguiar, E. K. Brathwaite and Claude McKay) and has also published on the works of Seamus Heaney, Salman Rushdie, Athol Fugard and Wole Soyinka, often with an emphasis on genre. 